\title{
On two modern hybrid forms of consequentialism
}

\author{
Lukáš Švaňa
}

\begin{abstract}
The article deals with two consequentialist theories and their comparison in terms of promoting certain values and evaluation of moral agents' actions and behaviour. A basic presupposition is their mutual compatibility based primarily on their consequentialist nature. The paper searches for possible evidence that presented theories might be denominated as hybrid theories based on their dynamic transformations and it also searches for possible mutual enrichment of these theories/approaches as their examined similar character might be a good starting point for such goals. The nature of ethical values is questioned as well as the idea (supported by relevant argumentation) of not distinguishing ethical theories based on their implicit inclination towards usage of specific values. The paper confronts these traditional (classical) ideas of making such differentiation and thus strictly connecting specific moral values with specific ethical theories and not allowing possible productive associations. Ethics of social consequences and the theory of lesser evil are chosen as examples to prove that not limited approaches in terms of operation with only specific type of values might be productive. Their dynamic character predestines these theories to be hybrid ethical theories and thus compatible in their value structure and theory of right.
\end{abstract}

Keywords: consequentialism, ethics of social consequences, lesser evil theory, values

\section{Introduction}

Consequentialist theories are theories that evaluate the actions of a moral agent primarily by the consequences they tend to bring. "It must be stressed that consequences in consequentialism are just one of the ways of evaluating acts (not the only one, though the most important)" (Kalajtzidis, 2013a, p. 163). I am in accordance with Ján Kalajtzidis' understanding of consequentialist theories which states that "consequentialism is not a complex ethical theory. The notion, in its contemporary understanding, serves for denomination of a group of ethical theories with close (similar) features and common basis" (Kalajtzidis, 2013b, p. 135). According to Philip Pettit, the main difference between consequentialist and non-consequentialist theories is in their distinct approach to the theory of right. The consequentialist approach tends to promote values chosen by moral agents, while the non-consequentialist approach tends to honour values as it claims that there are values that should be honoured and respected (Pettit, 1989, p. 117). One of the latest trends in modern forms of consequentialism is their "interest" in implementing ethical values that are traditionally assigned to non-consequentialist theories i.e. theories that are not oriented on evaluating moral agents' actions based on their consequences. The present paper deals with questioning whether it makes any sense to differentiate ethical theories based on their inclination towards certain specific values and approaches. It confronts a specific ethical theory i.e. ethics of social consequences with the theory of lesser evil in context of their implementation of ethical values and/or their possible violation. Both theories are presented as hybrid ethical theories i.e. theories that originated as classical ethical theories, but due to dynamic changes and new problems and challenges arising in the second half of the $20^{\text {th }}$ century have been gradually transformed. In one of his latest works, Kalajtzidis mentions 
Thomas Nagel and Samuel Scheffler as pioneers of hybrid ethical theories. ${ }^{1}$ A hybrid ethical theory is a theory that is open to dynamic change and transformation if it is the subject of criticism and such theories are characterized by two elements. Firstly, it is an original (one sided, classical) position that the theory holds upon and secondly, it is a new element that seems to be incompatible with the original position (Kalajtzidis, 2016). Hybrid ethical theories combine aspects of various ethical theories.

\section{Ethics of social consequences}

Ethics of social consequences is one of those theories identifying itself as a form of nonutilitarian consequentialism. In ethics of social consequences, "positive social consequences are the highest moral principle of our behaviour. Positive social consequences are consequences which tend to bring satisfaction of certain needs of a man, social community and society and they create possibilities for the development of creativity and skills and for the development of all creative potential of society" (Gluchman, 1994, p. 19). However, positive social consequences cannot be put on pedestal and Vasil Gluchman ${ }^{2}$ acknowledges that when later on, he claims: "[T]he core of ethics of social consequences is based on values of human dignity, humanity and moral rights that are in close connection with the value of positive social consequences" (Gluchman, 2008, p. 77). In fact, it is a reciprocal relationship with no superiority or inferiority among any of its members. I believe that the value of positive social consequences is a primary value, but accentuation of its fulfilment must be in close connection with other (primary and secondary) values. ${ }^{3}$ I believe that its original adherence to positive social consequences is the first (strictly consequentialist) element of its hybrid character and its gradual orientation towards evaluation of moral agents' motives and the promotion of the values of humanity, human dignity and moral rights as its second element. It even integrated the original value of legitimity into the value of humanity based on criticism of possible risks arising from identifying one with the other. ${ }^{4}$

According to its author, ethics of social consequences "tries to exceed a framework of traditional division of topics, principles and values into deontological and consequentialist, because it stresses questions of humanity, human dignity that are being perceived as a domain of deontology" (Gluchman, 1999, p. 61). Nowadays, it has become more and more evident that such division does not make any sense as many different types of frameworks and methodologies work with various notions and can operate with them with new unexplored approaches. One of the most common accusations made against consequentialist theories is of

\footnotetext{
${ }^{1}$ For more relevant information on these authors and their versions of hybrid ethical theories as well as on their origins, see: Hybridné tendencie v kontexte normatívnych koncepcií na príklade etiky sociálnych dôsledkov [Hybrid tendencies in normative conceptions with ethics of social consequences as an example] (Kalajtzidis, 2016).

${ }^{2}$ Vasil Gluchman is the founder of ethics of social consequences and he has developed it as a consequentialist theory. Among his best known works are: Miesto humánnosti v etike sociálnych dôsledkov [A place of humanity in ethics of social consequences] (Gluchman, 2005), Etika sociálnych dôsledkov a jej kontexty [Ethics of social consequences and its contexts] (Gluchman, 1996), Etika a reflexie morálky [Ethics and reflections of morality] (Gluchman, 2008), and many others. Ethics of social consequences strives to be a dynamic, flexible theory and a practical approach and Gluchman "puts it into practice" when he applies in to various fields of (practical) ethics e.g. Profesijná etika ako etika práce a etika vztahov [Professional ethics as work ethics and ethics of relationships] (Gluchman, 2014), Ethics of social consequences - Methodology of bioethics education (Gluchman, 2012a), Profesijná etika v kontexte konzekvencialistického uvažovania (ESD model profesijnej etiky) [Professional ethics in context of consequentialism (ESC model of professional ethics)] (Gluchman, 2012b), etc.

${ }^{3}$ Among secondary values, we can identify: justice, tolerance, responsibility and moral duty.

${ }^{4}$ Originally, the principle of legitimity was an independent principle, but later on it became an inherent part of the principle of humanity as a reaction to possible misusage and misunderstanding of the two principles (Gluchman, 1999b, p. 49).
} 
its effort to achieve an "agent-neutral" position, i.e. the principle of impartiality. ${ }^{5}$ The problem is that such a position is typical for utilitarianism as a traditional and classical form of consequentialism. Among such critics of utilitarianism are Bernard Williams, Samuel Scheffler and Philippa Foot. ${ }^{6}$ Some ethical theories, mainly deontological in nature, seem to usurp values such as human dignity and thus they seem to refuse that these values might be a part of consequentialist ethical theories. I agree with Gluchman's opinion that "moral values cannot be identified with specific ethical theories based on formal criteria only" (Gluchman, 1999a, p. 113). Any value can be a part of any ethical theory/system as long as it does not violate its basic premises and conditions. The second element in any hybrid ethical theory (mentioned above) seems incompatible at first, but its further application might prove its contribution towards making the theory more dynamic and flexible. Therefore, we cannot disqualify any value a priori simply by treating it as consequentialist, deontological or linked with any other type of ethical theory.

The value structure of ethics of social consequences is close to Amartya Sen's approach to values. Ethics of social consequences accepts, develops and realizes values which are part of many other ethical, many times non-consequentialist, theories (Gluchman, 2012a, p. 17). Ethics of social consequences tries to prove that certain values (humanity, human dignity, moral right, etc.) can constitute an inherent part of consequentialist theories as they are presuppositions for positive consequences. Their mutual cooperation presupposes an emergence of positive social consequences or at least minimizing the occurrence of negative social consequences. Unless this condition is fulfilled, an act cannot be evaluated as moral according to ethics of social consequences and its theory of right. ${ }^{7}$ The theory of right is strongly influenced by respecting or violating certain basic principles built around certain values. The content of each value is essential. Differentiation of ethical theories based on the values and principles, they operate with, makes no sense as different ethical theories might use particular values in their own manner supported by relevant arguments. Ethics of social consequences tries to prove that such a connection is possible and more importantly, productive in terms of making peoples' lives better and more valuable.

The aim of this paper is to present relevant evidence to declare the hybrid character of two consequentialist theories in terms of the value structure and dynamic character of both presented theories. The question is whether their modification might not possibly result in their shifting towards utilitarianism as a form of pure consequentialism or whether they can withstand possible criticism based on their hybrid character and still remain in the position of modified (hybrid) forms of consequentialism. The reason for such questioning is obvious: nowadays, many theories claim themselves to be consequentialist that general discussion has reached a point where there are multiple versions of consequentialism that might even oppose each other in their significantly diverse approaches. Theoretical reasoning inherent to the theory of right might be of key importance to a better understanding of the complexity of ethics of social consequences as hybrid ethical theory. The theory of right of ethics of social consequences originated from George Edward Moore's theory of right who was one of the first to formulate the theory of right, but according to him, pain and pleasure were primary criteria for evaluation of the rightness and wrongness of actions (Moore, 2005, pp. 31-34).

\footnotetext{
${ }^{5}$ The principle of impartiality is a traditional principle of classic utilitarianism which refers to the imagined impersonal perspective from which, it is supposed, moral judgments are to be made. It demands to assign the same moral value of all moral subjects involved in the decision-making process on the level of morality.

${ }^{6}$ For more information on this criticism of classical (utilitarian) consequentialism, see: A critique of utilitarianism (Williams, 1973), Consequentialism and its critics (Scheffler, 1991), The rejection of consequentialism (Scheffler, 1994) and Utilitarianism and the virtues (Foot, 1988).

${ }^{7}$ I believe that for purposes of achieving goals of this paper, it would be irrelevant to present the details of its theory of right, for more information on ethics of social consequences' theory of right, see: Etika a reflexie morálky [Ethics and reflections of morality] (Gluchman, 2008).
} 
Gluchman writes that "while categories of right and wrong are absolutely or at least considerably connected with the utilitarian-hedonistic value of pleasure, this value does not take any special role in ethics of social consequences" (Gluchman, 2008, p. 12). Based on this distinction, Moore uses categories of right and wrong in different connotations, however his theory of right is complex, an analytical and comprehensive method of evaluating human behaviour, its alternatives and consequences. Adoption of Moore's theory of right and its modification into a relatively different model of evaluating the actions and decision making of moral agents is another example of dynamic changes in the theory. The originally adopted model of assigning rightness and wrongness based on the production of positive consequences is modified to a position in which prevalence of these positive consequences is sufficient and their inclination towards pleasure and indifference towards pain is partly ignored. What matters most are positive consequences in their most extensive manifestations and their prevalence over negative consequences.

The rightness, wrongness, morality and immorality of an action are conditioned by promoting values of positive social consequences, humanity, human dignity and moral rights. One of the problems mentioned by Kalajtzidis is that it is not clear whether ethics of social consequences acknowledges the difference between promoting and respecting certain ethical values (Kalajtzidis, 2013a, p. 161). Pettit's above mentioned division line between consequentialist and non-consequentialist theories based on the theory of right and promotion of values as a domain of consequentialism while respecting values as a characteristic counterpart for non-consequentialist theories (Pettit, 1991, pp. 230-231) is an important issue and deserves further consideration. The danger of uncritical promotion of certain values in consequentialist theories can be found in the possibility of their promotion at the expense of other "less important" values or in the inclination towards simplistic calculation of positive and negative social consequences and thus becoming a strictly consequentialist theory identified as pure consequentialism. The position of pure consequentialism holds that the justification of practice depends only on its consequences (Duff, 2001, p. 3). Actions that we decide to perform become right if they accomplish their objective - minimize negative social consequences (or produce positive social consequences and minimize suffering, pain and evil). But evaluation of actions exclusively based on their consequences and effectiveness is an extremely pragmatic position. Identifying consequentialism with utilitarianism is a mistake we must eliminate at the beginning. On the other hand, concepts of civil liberalism are an example of an opposing radical position in which some actions remain wrong even if they accomplish their goals and no violation of human rights can be justified. Such a deontological approach is based on respecting values rather than promoting them.

Despite Kalajtzidis' claim that ethics of social consequences remains on the side of consequentialism in terms of promotion when compared to respecting values as seen in promotion of the value of humanity as an example (Kalajtzidis, 2013a, p. 161), I believe its promotion of values is not as strict as that of pure consequentialism. As a hybrid ethical theory, ethics of social consequences stands in the middle i.e. it is not extremely consequentialist and not strictly deontological (despite using the value of moral duty as a value of secondary importance). But as said above, division of ethical theories based on the values they use and apply does not make sense in terms of modern (hybrid) ethical theories and so ethics of social consequences is identified as consequentialist theory (obviously nonutilitarian) by promoting values and especially the value of positive social consequences accompanied by the values of humanity, human dignity and moral right. There seems to be a certain similarity between ethics of social consequences and the theory of lesser evil. One of the aims of the proposed comparison is to reflect on these theories in terms of their consequentialist nature and possibly prove their worthiness and mutual interconnection by 
confronting their ideas and approaches and possible modifications as clear declaration of their hybrid dispositions.

\section{The Theory of Lesser Evil}

The theory of lesser evil presented for the purpose of this paper is presumably one of many theories that operate with the concept of something (usually an action and its connection with its consequences) being a lesser evil. Nevertheless it is aimed at minimizing negative consequences (greater evils). The tradition of the concept itself is as old as humanity itself, but one of the first theoretical frameworks dealing with the issue of lesser evil was Thomas Aquinas' doctrine of double effect in which he "applies the doctrine to situations in which causing harm and/or killing a person may seem inevitable and required to ensure the greater good. I believe that the doctrine itself is a version of the theory of right as it stipulates which actions can be performed and still be judged as right and justifiable. It also, though indirectly, specifies actions that should be avoided on the basis that they are wrong and unjustifiable" (Švaňa, 2016, p. 65). The main idea of the theory of lesser evil is that consequences might be important to an extent when it would be permitted to violate certain principles that we consider as primary (in the particular theory) and pillars of liberal democracy in order to prevent the greater evil from occurring. It might seem paradoxical if we claim that protecting and promoting the value of humanity can be achieved by violating it. ${ }^{8}$ Such actions might be of lesser evil, but its necessity does not change our evaluation of it as wrong. Disregarding the principles of ethics of social consequences, it is entirely possible to claim that such types of actions can be right for two reasons. Firstly, they are based on the good motives and intentions of a moral agent (e.g. saving innocent citizens, preventing harm and damage and its anticipation, avoiding greater evil itself, etc.). Secondly, such acts cause more positive social consequences to occur despite unintended negative social consequences as an unwanted and unintended side effect. The crucial difference here is whether negative social consequences were intended or only foreseen. Foreseeing something does not mean intending something to happen and therefore one cannot be blamed for foreseeing something but rather for intending it.

One of the personalities dealing with the theory of lesser evil in the context of political ethics is Michael Ignatieff and his position seems acceptable and comparable to ethics of social consequences for many reasons. "It maintains that consequences can matter so much, for example, saving thousands of people from terrorist attack, that it might be worth subjecting an individual to relentless - though nonphysical - interrogation to elicit critical information. But this style of interrogation, which would push suspects to the limits of their psychological endurance, would remain a violation of their dignity. It would be a lesser evil than allowing thousands of people to die, but its necessity would not prevent it from remaining wrong" (Ignatieff, 2004, pp. 7-8). Violation of human dignity is necessary in such cases in order to avoid greater evil occurring. Actually, democratic societies should implement such practices, if necessary. An act would be inhumane and not respecting the value of human dignity ${ }^{9}$, but right. The original (classical) position of this theory is based on

\footnotetext{
${ }^{8}$ Alan Milne had a similar idea when he contemplated on human rights and their obedience in times of war and he came to the conclusion that "combatants (fighters, soldiers) cannot respect rights of other combatants.... therefore war as a means for securing respect for human rights has the drawback that it necessarily involves not respecting them" (Milne, 1986, p. 171).

${ }^{9}$ There are certain extreme conditions in which we can claim that such act would not violate the value of human dignity. The reason for such conclusion is simple - loss of any extent of the value of human dignity on an axiological level based on the previous actions of a suspect. Ethics of social consequences does not deal with this issue properly when Gluchman states that "not every single action in a specific time is a reason to increase or decrease an extent of the value of human dignity of and individual based on his actions" (Gluchman, 2008, p. 110). Considering the nature of consequences resulting from one's actions seems inevitable because ethics of
} 
evaluating actions based solely on their consequences (consequentialist policy) and specifically on their ability to stop greater evils occurring. The element added is necessity to act in order to prevent greater evils happening. The way in which this necessity is expressed is similar to deontological rules as it requires abidance to such rules. The reasoning behind such argumentation is deontological in nature because it is based around the concept of people as ends, rights and responsibilities. Demand for democratic societies to adopt such practices if necessary is clearly a call for adoption of certain rules and obligations and their strict abidance. This is the main reason why we should treat Ignatieff's theory as hybrid ethical theory.

Because measures to prevent greater evils from occurring are morally problematic, they must be strictly targeted, applied to the smallest possible number of people, used as a last resort, and kept under the adversarial scrutiny of an open democratic system. It is democracy and its institutions that should supervise the usage of lesser evil as one of the few partly justifiable measures for solving morally hazardous situations. Lesser evil has to stay under control by political measures and it is preceded by a great number of decisions and resolutions and tolerable bureaucracy. Without such control, measures to prevent greater evils occurring might become greater evils themselves. As these measures are disrespectful towards basic democratic values, the theory of lesser evil is based on the principle of equality of law and necessity. Here again, the shift towards the usage of moral obligation supports hybrid characterization of the theory. Moreover, its affinities with ethics of social consequences are obvious. By avoiding greater evil and promoting the idea of performing actions of lesser evil or letting actions of lesser evil happen, the moral agent is minimizing negative social consequences and thus promoting the principle of positive social consequences presented in ethics of social consequences. What is different is the fact that while ethics of social consequences is stricter when reflecting on violation of its primary principles, the theory of lesser evil is far more benevolent. In order to attain positive social consequences in specific situations, one should reconcile resorting to lesser evil i.e. actions and/or behaviour that directly violates certain values and principles present in contemporary consequentialist theories. Greater evil is identified as a far more negative consequence in the case of our inaction and hesitation (e.g. more lives lost, more damage and harm done, etc.)

As Ignatieff writes: "A lesser evil morality is designed for sceptics, for people who accept that leaders will have to take decisive action on the basis of less than accurate information who think that some sacrifice of liberty in times of danger may be necessary" (Ignatieff, 2004, p. 9). Benefits of such a theory are in its flexibility, adaptation and situational conditionality. On the other hand, it warns us of one-sided preference of one value or principle. Ignatieff proposes an idea of trade-off between the security of citizens and their liberties and rights. "Rights may have to bow to security in some instances, but there had better be good reasons, and there had better be clear limitations to rights abridgments; otherwise, rights will soon lose all their value" (Ignatieff, 2004. p. 9). Rights and liberties of the majority of citizens is determined by their security and if people live in fear, then they are not free i.e. the security of the majority becomes an imperative in Ignatieff's theory. The inherency of moral obligations is a significant sign of the overlapping character of the theory as it comprises classical consequentialist evaluation of actions with a moral imperative designed around protecting the

social consequences is primarily oriented on social consequences not limited to the sphere of an individual. Therefore, consequences that reach more people in terms of social good are more important and they shall increase or even decrease the value of human dignity of an individual to a greater extent. In my opinion, the method we use to assign value of human dignity is not specified and thus problems become more complex. It would be useful to differentiate consequences on macro-social and micro-social level and differentiate actions that (based on their consequences) cause the value of human dignity to increase or decrease to various extents. 
security of people and thus preserving the best outcomes and simultaneously avoiding negative consequences in form of greater evil.

When it comes to the situational character of the theory of lesser evil, we have to bear in mind that our particular actions that are supposed to be lesser evils have to be temporary solutions and used as a last resort. Democratic society is built upon certain principles and values and these limitations cannot simply be overlooked and disregarded. In other words, the trade-off principle is limited to a certain extent in order not to eventuate into permanent abidance as it might consequently result in a situation much worse that the original one. Despite this deontological moment in the theory, consequentialist argumentation must prevail. Eve Garrard claims that "Ignatieff's lesser evil theory is a middle way: neither rights nor security, he thinks, is always most important or can always act as trumps. The violation of rights is always morally wrong, in his view, but nonetheless it is sometimes necessary to preserve democracy against those who would bring it down" (Garrard, 2005, p. 30). She also proposes an idea that there are two greater evils which the theory of lesser evil tries to avoid. Firstly, it is the adoption of a purely consequentialist view in which any action which protects democratic society should be adopted and secondly, the other greater evil results from what she calls perfectionism - the view that rights must act as absolute constraints on action, so that we are never justified in violating them (Garrard, 2005, p. 30). On the other hand, such a position remains on the level of deontology. If the theory is in the middle-way position (according to Garrard), it must therefore be a position of adopting multiple (or at least double) paradigms (or their elements) and thus it is a hybrid theory. Peyman Vahabzadeh criticizes Ignatieff's theory for being pragmatic ethics of lesser evil and claims that "his concept of evil has no philosophical foundations in the theory of justice" (Vahabzadeh, 2005, p. 125) and "remains parochially pragmatic and as such caught in the systematic hubris that defines our world system by the institutionalized violence that reproduces itself in counter-violence, ad infinitum" (Vahabzadeh, 2005, p. 127). Re'em Sagev asks how is it possible to justify the actions of lesser evils despite indicating their wrongness (Sagev, 2005, p. 822). Isn't justice a predisposition for an action to be good or at least right? Justice as a secondary value in ethics of social consequences is important as it also influences the evaluation of an act. The value itself can be temporarily overlooked if the above mentioned criteria for avoiding greater evil are fulfilled. Sagev explains that the idea of lesser evil conflates the meta-ethical puzzle regarding the existence of moral dilemmas in which all options are wrong and the controversy of substantive moral theories. "Particularly, Ignatieff's meta-ethical view - that there are true moral dilemmas - and his substantive moral view - that both consequences and rights matter - do not entail one another" (Sagev, 2005, p. 821). Such criticism is based on the argument of incompatibility of two distinct elements in a single theory. Despite this apparent incompatibility, further analysis proves that such conjunction is productive in terms of its flexibility and situational character which seems to be a more adequate approach when evaluating the actions of moral agents. I perceive it as the main asset of hybrid moral theories i.e. a dynamic range of evaluation of a human's actions and the possibility of its justification based on other criteria than just consequences.

\section{Conclusion}

Both ethics of social consequences and the theory of lesser evil are evidently consequentialist theories as they strive for minimizing negative consequences (evil, greater evil) and for promotion of positive consequences (good, lesser evil). They are not strict and radical in terms of reaching and preserving such consequences and they both realize how problematic a situation might be. Lesser evil theory is appropriately designed around the central idea that there are evil actions and consequences in our societies and it must be a moral imperative to reduce them to minimum. It lacks a proper theory of right and this shortcoming is noticeable 
when it comes to evaluation of an action which does not promote certain values in order to promote them on a greater scale. This evident paradox is theoretically possible in ethics of social consequences as well, but there is one difference. While the theory of lesser evil evaluates such actions as wrong, ethics of social consequences admits that it might a right action even though it is not just. Both theories are open to modifications and that is another difference between them and other (radical) forms of consequentialism i.e. utilitarianism. While utilitarianism is primarily based on the calculation of consequences and cool rationality, ethics of social consequences and lesser evil theory are far more complex as they add certain principles into the process of evaluation of actions and behaviour, although they cannot avoid calculations to a certain extent, which is clearly visible in the notional apparatus they use. The apparent incompatibility of the element added in both theories constitutes them as hybrid ethical theories. While ethics of social consequences focuses on prevalence of positive social consequences over negative (or at least minimizing negative ones) and simultaneously considering the intentions and values of humanity, human dignity and moral rights, the theory of lesser evil focuses on avoiding greater evil and implementing certain actions that are evaluated as lesser evil with a simultaneous call for specific moral obligations and rules to preserve the security and freedom of people.

Both theories allow and/or call for specific types of actions on specific occasions or in extremely specific events. Gluchman explicitly states that "no value is considered to be absolute i.e. a value that should be respected absolutely and without limits. That means that in certain specific conditions, for example, the value of dignity, including the value of human dignity can be violated in order to preserve and secure considerable amount of other values" (Gluchman, 2008, p. 101). This question remains open in terms of what type of other values can be promoted/secured over some primary values. Finding that certain values can be promoted over others is of crucial importance because it means that this type of theory is dynamic and highly contextually conditioned.

Despite Ignatieff's interest in political ethics and the majority of his thoughts being applied to situations when we fight evil such as terrorism, I have tried to generalize some of his ideas to make them comparable with the ideas of ethics of social consequences. This comparison might be productive in two ways: first, it searches for possible conjunctions of two theories that are not strictly associated with a particular type of values i.e. they become hybrid moral theories and they are evidently applicable to situations that are outside normal situations of everyday life. Secondly, it is a starting point for possible enrichment of both theories in order to eliminate their limitations. Ethics of social consequences' theory of right should serve as inspiration for the theory of lesser evil. The theory of lesser evil lacks a proper theory of right and does not differentiate actions into moral, immoral, right and wrong and therefore it might be beneficial to make such distinctions. On the other hand, ethics of social consequences might adopt a position in which choosing a lesser evil would be beneficial for future expected consequences. I would suggest that such mutual enrichment of the two ethical theories in certain contexts might be highly useful if we are to better understand the nuances between ethical theories as such. This article is a declaration that such conjunctions are not only possible but they also form our rationality in terms of more precise evaluation of the actions and behaviour of people.

The article is an output of the grant VEGA 1/0629/15 Ethics of social consequences in context with other ethical theories.

Lukáš Švaňa is a senior lecturer at the Institute of Ethics and Bioethics, University of Prešov (Slovakia). His main research interest is in political ethics, ethics of war and questions of 
violence and terrorism, as well as reflections of their use and justifiability in the modern world. He is the author of scholarly papers e.g. Military ethics; A crisis of democracy, security and terrorism; The principle of non-combatant immunity - interpretations, challenges, suggestions and many other.

\section{Corresponding author:}

Lukáš Švaňa, Institute of Ethics and Bioethics, University of Prešov, 17. novembra 1, SK08078 Prešov (Slovakia)

Email: lukas.svana@unipo.sk

\section{References}

DUFF, R. A. (2001): Punishment, communication and community. Oxford: Oxford University Press.

FOOT, P. (1988): Utilitarianism and the virtues. In: S. Scheffler (ed.): Consequentialism and its critics. Oxford: Oxford University Press, pp. 224-242.

GARRARD, E. (2005): The lesser evil: Political ethics in an age of terror. In: Democratiya, 1(2) [online] [Retrieved September 18 2015] Available at: http://www.dissentmagazine.org/ democratiya_article/the-lesser-evil-political-ethics-in-an-age-of-terror

GLUCHMAN, V. (1994): Angažovanost', solidarita, zodpovednost' [Commitment, solidarity, responsibility]. Prešov: Universum.

GLUCHMAN, V. (2012a): Ethics of social consequences - Methodology of bioethics education. In: Ethics \& Bioethics (in Central Europe), 2(1-2), pp. 16-27.

GLUCHMAN, V. (2008): Etika a reflexie morálky [Ethics and reflections of morality]. Prešov: FF PU.

GLUCHMAN, V. (1996): Etika sociálnych dôsledkov a jej kontexty [Ethics of social consequences and its contexts]. Prešov: PVT.

GLUCHMAN, V. (1999a): Etika sociálnych dôsledkov v kontextoch jej kritiky [Ethics of social consequences in context of its criticism]. Prešov: LIM.

GLUCHMAN, V. (2005): Miesto humánnosti v etike sociálnych dôsledkov [A place of humanity in ethics of social consequences]. In: Filozofia, 60(8), pp. 613-623.

GLUCHMAN, V. (2014): Profesijná etika ako etika práce a etika vzt'ahov [Professional ethics as work ethics and ethics of relationships]. Prešov: FF PU.

GLUCHMAN, V. (2012b): Profesijná etika v kontexte konzekvencialistického uvažovania (ESD model profesijnej etiky) [Professional ethics in context of consequentialism (ESC model of professional ethics)] In: V. Gluchman (ed.): Profesijná etika - minulost' a pritomnost' [Professional ethics - past and present]. Prešov: FF PU, pp. 42-65.

GLUCHMAN, V. (1999b): Vývoj a postavenie humánnosti v etike sociálnych dôsledkov [Development and place of humanity in ethics of social consequences]. In: V. Gluchman (ed.): Reflexie o humánnosti a etike [Reflections on humanity and ethics]. Prešov: LIM, pp. 48-59.

IGNATIEFF, M. (2005): The lesser evil: Political ethics in an age of terror. Toronto: Penguin Canada.

KALAJTZIDIS, J. (2013a): Ethics of social consequences as contemporary ethical theory. In: Ethics \& Bioethics (in Central Europe), 3(3-4), pp. 159-171.

KALAJTZIDIS, J. (2013b): Etika sociálnych dôsledkov ako forma neutilitaristického konzekvencializmu [Ethics of social consequences as a form of non-utilitarian consequentialism]. In: V. Gluchman (ed.): Etika na Slovensku v súčasnosti (od 2. polovice 20. storočia). Prešov: FF PU, pp. 135-149. 
KALAJTZIDIS, J. (2016): Hybridné tendencie v kontexte normatívnych koncepcií na príklade etiky sociálnych dôsledkov [Hybrid tendencies in normative conceptions with ethics of social consequences as an example]. In: V. Gluchman (ed.): 16. medzinárodná konferencia ETPP 2016/16 [16th International conference (ETPP 2016/16)]. Prešov: FF PU (forthcoming).

MILNE, A. J. M. (1986): Human rights and human diversity: An essay in the philosophy of human rights. New York: State university of New York.

MOORE, G.E. (2005): Ethics. Oxford: Clarendon Press.

PETTIT, P. (1989): Consequentialism and respect for person. In: Ethics, 100(1), pp. 116-126.

PETTIT, P. (1991): Consequentialism. In. P. Singer (ed.): A companion to ethics. Oxford: Basil Blackwell, pp. 230-241.

SAGEV, R. (2005): Review of Michael Ignatieff, The Lesser Evil: Political Ethics in an Age of Terror. In: Ethics, 115(4), pp. 821-824.

SCHEFFLER, S. (1991): Introduction. In: S. Scheffler (ed.): Consequentialism and its critics. Oxford: Oxford University Press, pp. i-xx.

ŠVAŇA, L. (2016): Charlie Hebdo attacks in the light of Aquinas' doctrine of double effect and Ignatieff's lesser evil theory. In: Human Affairs, 26(1), pp. 63-72.

VAHABZADEH, P. (2005): The Secular Good in Denial: The Lesser Evil and the Politics of Fright. In: Journal for Cultural and Religious Theory, 6(2), pp. 117-129, [online] [Retrieved September 20 2016] Available at: http://www.jcrt.org/archives/06.2/vahabzadeh.pdf

WILlIAMS, B. (1973): A Critique of Utilitarianism. In: J. J. C. Smart \& B. Williams: Utilitarianism: For and against. Cambridge: Cambridge University Press, pp. 77-150. 